\title{
Prevalence of hookah smoking and associated factors among male high school students in Iraq
}

\author{
Ahmed K. Al-Delaimy ${ }^{1 *}$ and Waleed A. T. Al-Ani ${ }^{2}$
}

\begin{abstract}
Background: The use of the hookah-smoking device is increasing at a large scale in the Eastern Mediterranean region. Hookah users are exposed to an array of chemical compounds and may suffer several chronic diseases as a result. The purpose of this study was to determine the prevalence of hookah use among male high school students in the region and to study different associated factors in order to provide local tobacco control officials with an understanding of this public health problem.

Methods: A convenient non-probability sampling study was conducted among students in three high schools in Al-Karkh district, Baghdad. The study period was from October 2017 till January 2019 and included 847 male students aged 15-18 years old. Using a simple random technique to select the high schools from a list of schools we chose one school from each directorate. Descriptive, chi-square test of significance, bivariate, and multivariate logistic regression analyses of data were carried out for identifying the risk factors associated with hookah smoking among these high school adolescent males.
\end{abstract}

Results: The overall prevalence of hookah smoking in the last 30 days among male high school students was $46.1 \%$ while in the past 6 months it was as high as $85.7 \%$. More than two-thirds (70.6\%) of the students thought that hookah smoking was more socially acceptable than cigarette smoking. Factors such as having first heard about it from friends, the media, or the presence of a hookah café near their residence were significantly associated ( $p>$ 0.05) with hookah smoking among the students. Similarly, being surrounded by friends who used hookah was also found to be significantly associated with hookah smoking, with an odds ratio of $0.18,95 \% \mathrm{Cl}(0.087-0.394)$. Hookah smokers were less likely than non-hookah smokers to report its use as forbidden in Islam and more likely to say it is allowed in Islam.

Conclusions: We found an alarmingly high use of hookah smoking among male high school students in this study. Family members and peers had an important role in the prevention of hookah smoking among these students. There is a need for students to be educated about the toxicity of hookah tobacco smoking and its direct effect on their health.

Keywords: Prevalence, Hookah use, High school students, Risk factors, Iraq

\footnotetext{
* Correspondence: ahmedsoofi7@gmail.com

${ }^{1}$ Family \& Community Medicine Department / Anbar Medical College, University of Anbar, Ramadi, Iraq

Full list of author information is available at the end of the article
}

(c) The Author(s). 2021 Open Access This article is licensed under a Creative Commons Attribution 4.0 International License, which permits use, sharing, adaptation, distribution and reproduction in any medium or format, as long as you give appropriate credit to the original author(s) and the source, provide a link to the Creative Commons licence, and indicate if changes were made. The images or other third party material in this article are included in the article's Creative Commons licence, unless indicated otherwise in a credit line to the material. If material is not included in the article's Creative Commons licence and your intended use is not permitted by statutory regulation or exceeds the permitted use, you will need to obtain permission directly from the copyright holder. To view a copy of this licence, visit http://creativecommons.org/licenses/by/4.0/. The Creative Commons Public Domain Dedication waiver (http://creativecommons.org/publicdomain/zero/1.0/) applies to the data made available in this article, unless otherwise stated in a credit line to the data. 


\section{Background}

Globally, tobacco use is the second leading cause of mortality, and is responsible for the deaths of 1 in 10 adults [1]. Lung cancer is considered the leading cause of cancer mortality and is linked to the carcinogenic compounds found in tobacco smoke [2, 3]. Nicotine is known to decrease the body's immune response against malignant growth [4]. In addition to being linked to cancer, tobacco smoke causes several respiratory infections, and is also a factor in hypertension and diabetes, which, among others, are major risk factors for cardiovascular diseases. The effects of each of these risk factors potentiate the risk of cardiovascular events [5-7].

Hookah, also known as Shisha, Hubble-Bubble, Nargileh, and Water-Pipe (WP) smoking, is a common form of tobacco use in the Eastern Mediterranean. Although hookah smoking practices date back at least 400 years, the current use of these devices is increasing at large scale within the region, and is now also increasingly being used in Western countries $[8,9]$. Hookah design features a water bowl, hose, and mouthpiece [10]. Several studies have shown that hookah smoking contains harmful chemicals [11-14], and a single 45-min hookah session can expose the smoker to up to 48.6 times the amount of smoke from a cigarette $[10,15]$. In the United States (US), a significant increase in the use of hookah among high school students (4.1-7.2\%) was reported between 2011 and 2015 [16, 17]. Another study in the US showed that the percentage of both ever and current use of hookah was higher among males than females [18].

Young people have a misconception that hookah smoking is less harmful than cigarette smoking due to the filtration effects provided by the water [19]. However, levels of toxicants in a single hookah tobacco smoke puff can be multiple times higher than found in smoking a single cigarette [10]. These toxic substances include polycyclic aromatic hydrocarbons, nicotine, carbon monoxide, nitric oxides, formaldehyde, and others $[11,13,14]$.

Tumbak, Jurak, and Mu'assel are the most widely available types of hookah tobacco, each containing different added substances [20]. Tumbak is unflavored tobacco leaves (Ajami). Jurak contains tobacco, 20\% dried fruit, and sugarcane. Both are used widely in Asia and the Middle East. Mu'assel contains 70\% sugarcane, glycerol, flavorings, and 30\% tobacco [20-22]. The pleasant smell and mild taste from these flavored hookah tobaccos encourages their use, especially among adolescents. Some popular tobacco flavors include fruit, chocolate, spice, alcohol, menthol, candy, sweet, molasses, as well as many others [23-25].

In the Middle East several significant factors have been found to contribute to hookah smoking, including religion, friends and family, low-self-confidence, ready access to hookah devices, and their social acceptability [26-29].

However, there are few studies on hookah smoking behavior in Iraq, and these have mostly been focused on college students [30]. Therefore, our aim was to study the prevalence of hookah use among male high school students in Iraq and the different associated factors linked with hookah smoking with the goal of understanding how health policymakers and the government can approach this growing public health problem.

\section{Methods \\ Study design}

A cross-sectional survey in three high schools at AlKharkh district west of Baghdad was conducted between October 2018 and the end of December 2018, an area with a population of approximately 100,000 residents.

\section{Participants}

Male high school students aged 15 to 18 years old were eligible to participate in the study, which involved three different year levels, including 4th, 5th, and 6th (equivalent to 10th, 11th, and 12th grade high school levels in the US). A total of 1375 students were therefore invited from the three schools. However, the 6 th graders $(n=498)$ were subsequently excluded due to concerns from their school administration regarding participation in the study being potentially disruptive to their important final graduation year. The study participation rate was ultimately $96.5 \%$ with $847 / 877$ students completing the questionnaire after 30 students elected to drop out of the study.

\section{Sampling method}

The study used a convenience (non-probability) sample within one of the two Baghdad districts, Al-Kharkh and Risafa. Al-Karkh district, which is similar to Risafa on the opposite side of the Tigris River, was subsequently selected for the study. Although Al-Kharkh has multiple schools in its three educational directorates, due to limitations in available resources for this study, only one school from each directorate could be included. We therefore used a simple random technique to select which of the high schools from a list of schools to include from each. Each directorate has schools at its periphery that are $3-4 \mathrm{~km}$ away from its center with the other schools closer together and approximately $1-2 \mathrm{~km}$ from the district center. Due to additional securityrelated factors, we selected schools from each of the three directorates that were closer together, with 8 such schools within one directorate, 10 such schools in the second directorate, and 10 such schools in the third directorate. 


\section{Study size}

The study size was based on the sampling equation: $(n=$ $\left.\mathrm{Z}^{2} 1-\alpha / 2 \mathrm{P}(1-\mathrm{P}) / \mathrm{d}^{2}\right)$ where $n$ is the required sample size, $Z^{2} 1-\alpha / 2$ is the confidence interval $(95 \%=1.96, P=0.44$ estimated proportion), $\mathrm{d}$ is the 0.025 desired precision $[31,32]$. This resulted in a sample size of 847 students included in the study, with a level of significance at $5 \%$.

\section{Questionnaire}

Before circulating the final version of the questionnaire to the students, a pilot assessment was carried out among 28 students in one of the three schools (Al-Quds High School) to check the suitability of the Arabic questionnaire version.

The questionnaire was based on the California Tobacco Surveys for tobacco use [33] and modified to the social context of Iraq. It was translated from English to Arabic at the College of Literature in the Department of English at the University of Anbar. A questionnaire form was prepared with areas of questioning including, for example, the number of times that hookah tobacco was smoked in the past 30 days, how many hookah smoking sessions/day occurred among regular users, the level of confidence that the person felt they could quit hookah smoking, when the first time they heard about hookah was, their opinion about hookah smoking and Islam, and if they support regulations to close hookah cafés. The self-administered questionnaire was distributed to students by the first author, AKAD, to be completed in pencil and collected during class time. The survey was anonymous to protect privacy and ensure confidentiality. Questionnaire (English version) was added as supplementary file.

\section{Statistical methods}

Analysis of data was carried out using SPSS-25 (Statistical Packages for Social Sciences- version 25). The significance of the difference between percentage results (descriptive data) was tested using the Pearson chisquare test ( $\chi^{2}$-test) with the application of Yate's correction or Fisher exact test as applicable. Bivariate application and multivariate logistic regression analysis of data were carried out for comparison between independent variables among those who smoke hookah. All significant variables $(p<0.05)$ in the bivariate analysis were included in the multivariate analysis. Multivariate logistic regression analysis was used to investigate the significant risk factors for hookah smoking. The significance level for all the analyses was set at $p<0.05$. In logistic regression, the variable of "smoked hookah tobacco in the past 30 days" was the dependent variable and the categorical covariates (with a reference category for each covariate) were "first heard about hookah", "there are people surrounding students that smoke hookah", "the types of smoking that are most harmful to health", "is hookah smoking acceptable socially more than cigarette smoking", "hookah smoking is less harmful and less addictive than cigarette smoking", "student's opinion about hookah smoking in Islam", and "support regulations to close hookah cafés".

\section{Ethical issues}

Ethical clearance was obtained from both the ethical committee at Anbar University Medical College and the Directorate of Education at Al-Karkh district.

The ethics committee waived the need for written informed consent from the parents of study participants. Permission was obtained from the three school administrations to do the survey. School administration informed students verbally before the survey started that they would be asked to complete a questionnaire survey related only to hookah in the coming days, and that students would need to inform their parents. Direct verbal assent was also sought from the parents of high school students below the age of 16 . Written informed consent was obtained from the high school students, and they had the right to participate or refuse/withdraw from the study.

\section{Results}

The study participants consisted of 847 male high school students. The response rate was $96.5 \%$. Almost all data were normally distributed except for the variable 'regulation to close hookah café places' which had positive skewness (longer tail on the right).

\section{The prevalence of hookah smoking among students}

The prevalence of those who smoked hookah tobacco in the past 30 days was (46.1\%) (95\% CI $=42.8-49.9)$. We also found that 57 students had tried hookah smoking by having at least one puff (6.73\%) 95\% CI (4.9-8.5).

Hookah smoking among students in the past 6 months was $85.7 \%$, while more than a quarter $(28.1 \%)$ had tried hookah once in the last month (see Table 1). The highest percentage of students smoking hookah was among the ages of 15 and 16 (26.3\% \& 27.4\%, respectively). While the highest duration of smoking during each session was 30-44 $\mathrm{min}$ and $60-119 \mathrm{~min}, 24.3$ and $35.6 \%$ respectively (see Table 1).

\section{Social and cultural factors associated with hookah use}

Table 2 presents results on social and cultural factors associated with hookah use. The highest percentage of students first learned about hookah from friends (55\%) and most $(86.1 \%)$ knew that there was a café shop for hookah smoking near their residence. We also found that friends were the most common group reported to smoke hookah near students (65.2\%) (see Table 2). 
Table 1 Descriptive characteristics associated with hookah smoking (last 6 months), duration of hookah sessions, and other variables

\begin{tabular}{|c|c|c|c|}
\hline Variable \& Category & Frequency smoked & $\mathrm{n}$ & $\%$ \\
\hline \multirow{11}{*}{$\begin{array}{l}\text { Number of times smoked hookah } \\
\text { tobacco in the past } 30 \text { days. }\end{array}$} & 1 & 110 & 28.1 \\
\hline & 2 & 65 & 16.6 \\
\hline & 3 & 44 & 11.3 \\
\hline & 4 & 16 & 4.1 \\
\hline & 5 & 23 & 5.9 \\
\hline & 6 & 6 & 1.5 \\
\hline & 7---13 & 48 & 12.4 \\
\hline & $14--20$ & 32 & 8.3 \\
\hline & $21--27$ & 3 & 0.9 \\
\hline & $28--49$ & 32 & 8.2 \\
\hline & $\geq 50$ & 12 & 3.4 \\
\hline \multirow[t]{2}{*}{ Hookah smoked in the last 6 months } & Yes & 335 & 85.7 \\
\hline & No & 56 & 14.3 \\
\hline \multirow[t]{9}{*}{ Age first smoked hookah } & $<10$ years & 6 & 1.5 \\
\hline & 10 & 14 & 3.6 \\
\hline & 11 & 7 & 1.8 \\
\hline & 12 & 19 & 4.9 \\
\hline & 13 & 30 & 7.7 \\
\hline & 14 & 59 & 15.1 \\
\hline & 15 & 103 & 26.3 \\
\hline & 16 & 107 & 27.4 \\
\hline & $\geq 17$ years & 46 & 11.8 \\
\hline \multirow{5}{*}{$\begin{array}{l}\text { Hookah smoking sessions/day } \\
\text { among regular users }\end{array}$} & One & 52 & 13.3 \\
\hline & Two & 134 & 34.3 \\
\hline & Three & 121 & 31.0 \\
\hline & Four & 81 & 20.7 \\
\hline & Five \& more & 3 & 0.8 \\
\hline \multirow{4}{*}{$\begin{array}{l}\text { Sharing mouth-piece of hookah- } \\
\text { smoking device }\end{array}$} & Never & 120 & 30.7 \\
\hline & Sometimes & 135 & 34.6 \\
\hline & Most of the times & 59 & 15.1 \\
\hline & Always & 77 & 19.7 \\
\hline \multirow{5}{*}{$\begin{array}{l}\text { Student's confidence that he can } \\
\text { quit hookah smoking? }\end{array}$} & Completely confident & 239 & 61.2 \\
\hline & Confident & 83 & 21.3 \\
\hline & Some Confident & 30 & 7.7 \\
\hline & Not that Confident & 22 & 5.6 \\
\hline & Not Confident at all & 17 & 4.3 \\
\hline \multirow{6}{*}{$\begin{array}{l}\text { Duration of hookah smoking at } \\
\text { each session (minutes) }\end{array}$} & $<15 \min$ & 58 & 15.0 \\
\hline & $15-29$ & 20 & 5.1 \\
\hline & $30-44$ & 95 & 24.3 \\
\hline & $45-59$ & 24 & 6.2 \\
\hline & $60-119$ & 139 & 35.6 \\
\hline & $\geq 120 \mathrm{~min}$ & 55 & 14.2 \\
\hline
\end{tabular}

Islam's opinion regarding hookah smoking, socially acceptance and agreement on the regulation

In terms of the Islam's opinion regarding hookah smoking, students mostly reported this being either discouraged (47.3\%) or forbidden (20.9\%) (see Table 3).

More than two-thirds (70.6\%) of students believe that hookah smoking is more acceptable socially than cigarette smoking. There was agreement among more than three-quarters of students of the need for regulations to close or ban hookah cafés (81.5\%) (see Table 2).

\section{Bivariate analysis on the associations between related factors and hookah smoking}

The bivariate analysis demonstrated that the subgroup variables friends, media, and the presence of a hookah café near the student's residence were associated with students being more likely to smoke hookah compared to other subgroups in the same variable (first heard). Students were most likely to be using hookah if they had heard about it from friends (OR 1.4 (95\% CI $=1.07-$ 1.85)), while those who heard about hookah from the media were less likely to use it $(\mathrm{OR}=0.5,95 \% \mathrm{CI}=0.30$ 0.85) (see Table 3). Among the different groups of people in a student's life who smoke hookah we found that friends who smoked (OR $1.78(95 \% \mathrm{CI}=1.33-2.38)$ and a brother or sister who smoked were significant risk factors for students to be a hookah smoker themselves (OR 1.68 (95\% CI = 1.02-2.76) respectively)).

Also, we found that students were more likely to smoke hookah if there was a hookah café near their residence $(\mathrm{OR}=2.0$ (95\% CI: 1.36-3.13)). Among the four types of smoking listed on the survey, students believed that cigarettes have a more hazardous effect on human health than hookah $(43.5 \%$ Vs. $25.6 \%$; OR $=4.4)$. Those reporting that hookah smoking was accepted socially were much more likely to be hookah smokers $(\mathrm{OR}=$ 2.6), while those supporting regulation to close café places were less likely to be hookah smokers $(\mathrm{OR}=0.3$ ) (see Table 3).

\section{Multivariate analysis of the associations between related factors and hookah smoking}

Table 4 presents results that reveal the different risk factors associated with hookah smoking. This table includes all variables in the model based on the univariate results from Table 3. Results clearly indicate students who had family and friends who smoked hookah in their presence were more likely to also use it, although only the variable of having friends who smoked hookah reached statistical significance. Having a coffee shop that sells hookah near their house was also significantly associated with hookah use. If the students thought hookah is less harmful or more socially acceptable they were significantly more likely to use hookah (see Table 4). 
Table 2 Social and cultural factors associated with hookah users, including Islam's opinion about hookah use, social acceptance, and other variables

\begin{tabular}{|c|c|c|c|}
\hline \multirow{2}{*}{\multicolumn{2}{|c|}{$\frac{\text { Variable }}{\text { First, heard/know about Hookah? }}$}} & $\mathbf{n}$ & $\%$ \\
\hline & & & \\
\hline \multicolumn{2}{|l|}{ Father \& Mother } & 36 & 4.3 \\
\hline \multicolumn{2}{|l|}{ Brothers, Sister \& Cousin } & 143 & 16.9 \\
\hline \multicolumn{2}{|l|}{ Friends } & 466 & 55.0 \\
\hline \multicolumn{2}{|l|}{ Media and Newspaper } & 73 & 8.6 \\
\hline \multicolumn{2}{|l|}{ Saw a Hookah Café shop } & 120 & 14.2 \\
\hline \multicolumn{2}{|l|}{ Others (internet) } & 40 & 4.7 \\
\hline \multicolumn{2}{|l|}{ Presence of Cafe for hookah smoking around students' residence } & 729 & 86.1 \\
\hline \multicolumn{4}{|l|}{ People surrounding/near students that smoke hookah. } \\
\hline \multicolumn{2}{|l|}{ Father \&Mother } & 38 & 4.5 \\
\hline \multicolumn{2}{|l|}{ Brothers \&Sisters } & 69 & 8.1 \\
\hline \multicolumn{2}{|l|}{ Other close relatives } & 268 & 31.6 \\
\hline \multicolumn{2}{|l|}{ Friends } & 552 & 65.2 \\
\hline \multicolumn{2}{|l|}{ None } & 76 & 9.0 \\
\hline \multirow[t]{4}{*}{ Which of the following types of smoking are more harmful to health? } & Tobacco gum & 50 & 5.9 \\
\hline & Cigarette & 293 & 34.6 \\
\hline & e-cigarette & 202 & 23.8 \\
\hline & Hookah & 302 & 35.7 \\
\hline \multirow[t]{4}{*}{ Student's opinion for Hookah smoking in Islam. } & Forbidden & 177 & 20.9 \\
\hline & Discouraged & 401 & 47.3 \\
\hline & Allowed & 79 & 9.3 \\
\hline & Do not know & 190 & 22.4 \\
\hline \multirow[t]{2}{*}{ Is hookah smoking acceptable socially more than Cigarette smoking? } & Yes & 598 & 70.6 \\
\hline & No & 249 & 29.4 \\
\hline \multirow[t]{2}{*}{ Is hookah smoking is less harmful and addictive than cigarette smoking? } & Yes & 314 & 37.1 \\
\hline & No & 533 & 62.9 \\
\hline \multirow[t]{2}{*}{ Agree on regulations to forbid café places? } & Yes & 690 & 81.5 \\
\hline & No & 157 & 18.5 \\
\hline
\end{tabular}

\section{Discussion}

This is the first study to investigate the risk factors associated with hookah smoking among male high school students in Iraq. We found that although most students who smoked hookah had an accurate perception of how Islam views hookah smoking as forbidden or harmful, and most supported regulations against hookah cafés, the overall prevalence of hookah smoking among the students was high (46\%). This high rate of hookah use was similar to that found in a study of hookah use in secondary school adolescent males, aged $>18$ years, in Saudi Arabia, which was 44\% [32]. However, studies reported by Abbas et al and Alzyoud et al in Iranian and Jordanian male high school students found a different, much lower rate of 6 and $24 \%$, respectively [34, 35]. The high rate reported in the current study might reflect the acceptance and spread of such harmful behavior in such a young age group due to recent problems of conflict imposed on Iraq, making tobacco control less of a priority by the government. Our study is also the first to explore the multiple social factors associated with smoking hookah in this age group and also the first to consider the role of religion in this behavior. This can help provide health policymakers with the tools they need to develop policies or interventions to tackle this growing and serious public health problem. Our findings may also be applied to the Middle East as a whole, since the region shares is a similar culture and language and the use of hookah is increasing throughout.

More than half of participants first heard about hookah smoking from friends and more than two-third have friends who smoke hookah, which highlights the role of friends in initiating hookah smoking. Similar findings were reported by Azodi et al in Iran and Bejjani et al in 
Table 3 Bivariate analysis for association of different factors affecting hookah smoking

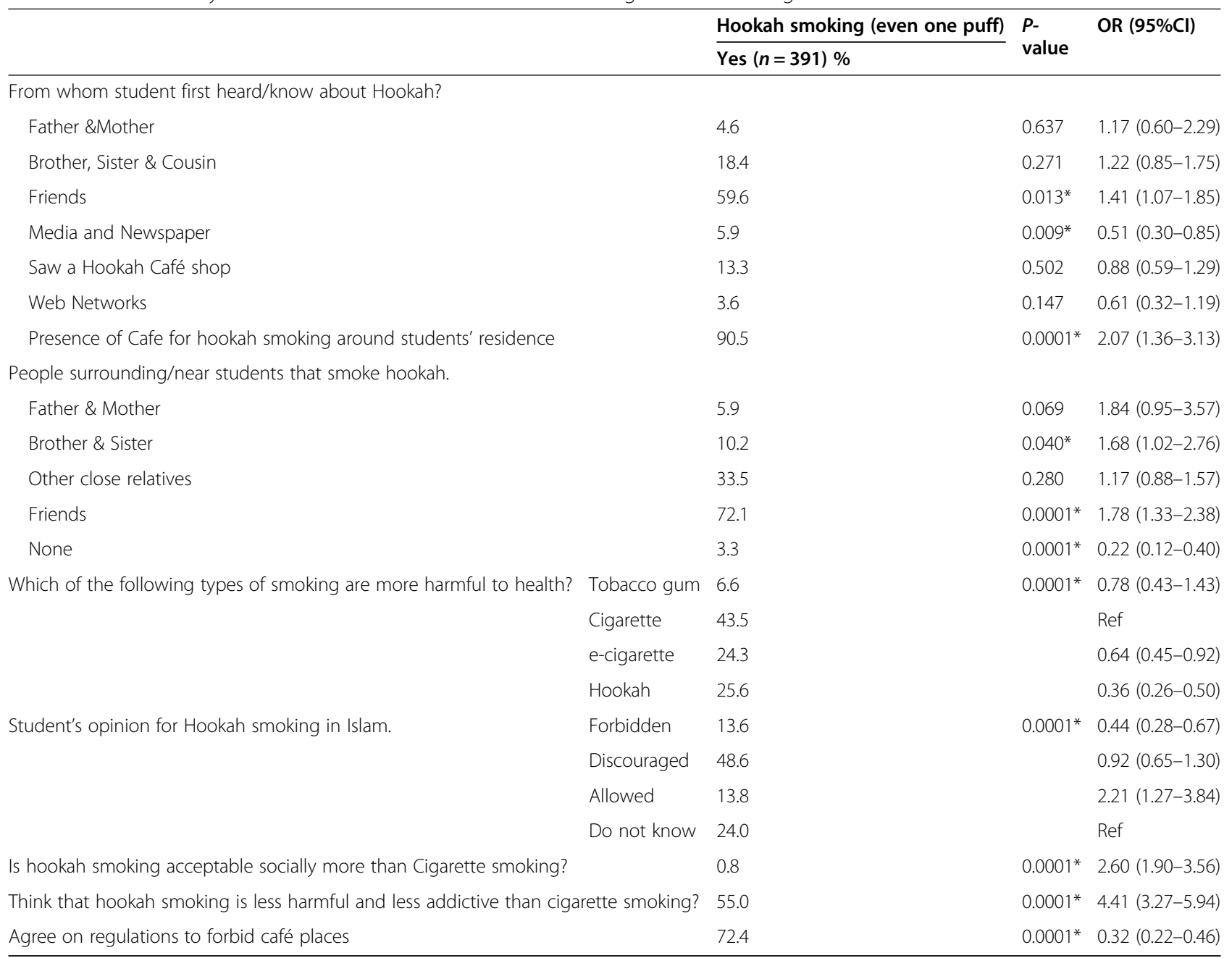

*Significant association using Pearson Chi-square test at 0.05 level

Lebanon [36, 37]. This points to the fact that a new generation of hookah users is present, unlike previous generations where it was not smoked as commonly as now.

Among different types of tobacco smoking, high school students in this study thought that hookah smoking caused more harm to health than nicotine gum or electronic cigarettes. Aslam et al. in their review explained the significant association between hookah smoking and increased risk of heart disease, cancer, and hypercholesterolemia [38]. Although adolescents in our study believe that hookah smoking had worse health effects than other types of smoking, they still used it. We believe this is likely due to the relatively pleasant aroma of the smoke, flavor, and taste of hookah smoking that can overcome an individual's perception of its harm. We believe this may also be influenced by peer pressure as hookah devices can bring groups of friends or other acquaintances together socially. This could explain the reason hookah smoking is seen as more acceptable socially than cigarette smoking. This agrees with findings from
Fitzpatrick et al. in the USA, Momenabadi et al in Iran and Tamim et al in Lebanon who reported attempts of hookah smoking among young adult users were associated with the belief that it is socially and culturally more acceptable than cigarette smoking [27, 39, 40], and this led to an increase in the prevalence of this behavior. Hookah may therefore present a greater challenge to changing social norms around its acceptance in society.

A high percentage of students believed hookah smoking was discouraged and forbidden in Islam (68.2\%) reflecting the important role that religion and faith can play in preventing smoking, as it does in regards to other risky behaviors such as gambling, drug abuse, and alcohol drinking [41]. A study from Jordan which looked into smoking habits among university students and academics at different levels found that individuals in the faculty of religious studies were less likely to smoke compared to those in other faculties [42].

Sajid et al. reported that carboxyhemoglobin concentration in cigarette smokers is lower $(6.1 \mathrm{ppm})$ than in 
Table 4 Multivariate logistic regression of risk factors affecting hookah smoking

\begin{tabular}{|c|c|c|c|c|}
\hline \multirow[t]{2}{*}{ Reference Category was the (first). } & \multirow{2}{*}{$\begin{array}{l}P \\
\text { value }\end{array}$} & \multirow{2}{*}{$\begin{array}{l}\text { Odds } \\
\text { Ratio }\end{array}$} & \multicolumn{2}{|c|}{ 95\% C.I. for odds ratio } \\
\hline & & & Lower & Upper \\
\hline \multicolumn{5}{|l|}{ First heard/know about Hookah? } \\
\hline Brother, Sister and cousin & .084 & 2.310 & .894 & 5.964 \\
\hline Friends & $.035^{*}$ & 2.635 & 1.069 & 6.496 \\
\hline Media \& Newspaper & .558 & 1.348 & .496 & 3.664 \\
\hline Saw a Hookah Café shop & .201 & 1.835 & .724 & 4.651 \\
\hline Web Networks & .101 & 2.711 & .823 & 8.931 \\
\hline \multicolumn{5}{|l|}{ People surrounding/near students that smoke hookah. } \\
\hline Brother \& Sister & .183 & 1.513 & .823 & 2.782 \\
\hline Close relatives & .173 & 1.345 & .878 & 2.059 \\
\hline Friends & $.017^{*}$ & 1.770 & 1.110 & 2.824 \\
\hline None & $.027^{*}$ & .374 & .157 & .895 \\
\hline There is a cafe for WP smoking around your residence & $.005^{*}$ & 2.817 & 1.362 & 5.827 \\
\hline \multicolumn{5}{|l|}{ Which of the following types of smoking are more harmful to health? } \\
\hline Cigarette & .620 & .837 & .415 & 1.690 \\
\hline e-cigarette & .991 & 1.004 & .486 & 2.075 \\
\hline Hookah & .316 & 1.437 & .707 & 2.920 \\
\hline Is hookah smoking acceptable socially more than Cigarette smoking?? & $.000^{*}$ & 1.996 & 1.389 & 2.868 \\
\hline Hookah smoking is less harmful and less addictive than cigarette smoking? & $.000^{*}$ & 3.703 & 2.656 & 5.162 \\
\hline \multicolumn{5}{|l|}{ Student's opinion for Hookah smoking in Islam. } \\
\hline Discouraged & $.002^{*}$ & .512 & .335 & .782 \\
\hline Allowed & $.000^{*}$ & .314 & .165 & .598 \\
\hline Don't Know & $.007^{*}$ & .513 & .315 & .836 \\
\hline Agree on regulations to forbid café places. & $.000^{*}$ & .391 & .257 & .594 \\
\hline
\end{tabular}

*Significant association using Pearson Chi-square test at 0.05 level

individuals who smoke shisha $(8.8 \mathrm{ppm})$ [43]. In the current study we found that more than three-quarters of adolescent hookah smokers reported smoking for $30 \mathrm{~min}$ or more at each session. This is concerning since duration of hookah smoking sessions, depth of inhalation, and frequency of puffing all contribute to the level of exposure to nicotine and other carcinogenic chemicals present in the charcoal and tobacco in shisha smoke. As mentioned above, hookah has high concentrations of a carboxyl group, nicotine, and other chemicals, even higher than cigarette smoking, and has an addictive impact on the body causing withdrawal symptoms when trying to quit. Despite this, three-quarters of the students in the current study reported that they can quit hookah smoking when they decide to.

Our multivariate logistic regression model showed a significant difference among subgroups who smoked around the students, reflecting the greater influence of family and peers on adolescent health and behavior [44]. Hookah use was the only significant sub-variable among the others in comparison with the reference category ecigarette. Also, hookah use was higher among those who said hookah smoking was socially acceptable and less harmful than cigarette smoking.

\section{Limitations and strength of the study}

Only one school from each directorate was selected to participate in this study due to the limitations in financial support and issues with security. Therefore, our use of a convenience sample may have impacted the generalizability of the study, although we believe that our results are representative of students from elsewhere in the district given there are similar social norms across the Iraq [45]. Although the Arabic version of the questionnaire was not validated, we did pretest the questionnaire prior to the main study and necessary modifications were made. In all three high schools, the school administration declined to enroll the sixth-grade (final graduation year) students in the study since they did not want to divert any student attention away from the task of completing their final and most difficult year prior to graduating on to University or College. If we had been able to include the sixth grade students we believe the factors we found associated with hookah use 
may have become more significant. Since the study was limited to male students, socio-demographic characteristics were not included in the questionnaire. Hookah is rarely smoked by females of high school age. Also, the study may have led to under reporting of use [45] given hookah and cigarette smoking in high school is not accepted legally. However, the students completed their questionnaires anonymously and thus we may assume their responses were candid.

\section{Policy implications}

School-aged children and other youth are the most appropriate group for intervention programs aimed at preventing hookah smoking. We believe this can be facilitated by carrying out regular surveys, for example every 2 years, with representative samples of young people in schools to assess prevalence of hookah smoking in this group and track its associated factors. Education techniques can also be used that are tailored to the socio-culture of even younger children (primary school level). Furthermore, socially based rather than information based prevention programs can be implemented to address the specific needs of particular youth cultures known to promote hookah use. It is also necessary to work with government to introduce a total ban on advertising of hookah smoking and ensure legislation is in place to limit hookah cafés and overcrowding. Overall, a comprehensive national and community strategy is needed to take action on the social, interpersonal and personal influences that lead to hookah use in youth.

\section{Conclusions}

This study reported an alarmingly high use of hookah tobacco smoking among male high school students in Iraq, and that it is an acceptable socio-cultural phenomenon among them. Effective control measures are required including health education, school intervention programs, and legislation against hookah cafés. Further studies are needed to compare similarly aged youth across the region and to understand the differences and similarities of this behavior and its public health impact.

\section{Abbreviations}

KAP: Knowledge, Attitude, Practice; OR: Odds Ratio; C.I: Confident Interval; WP: Water Pipe; e-cigarette: Electronic cigarettes

\section{Supplementary Information}

The online version contains supplementary material available at https://doi. org/10.1186/s12889-021-11386-4.

Additional file 1. Hookah Questionnaire (English version) was added as supplementary file.

\section{Acknowledgments}

The authors would like to thank Ms. Rachel Berquist for reviewing the manuscript.

\section{Authors' contributions}

AK conceived of the research idea, designed the methodology, collected data, performed the analysis and interpretation of data, wrote the first draft manuscript, and was in charge of overall planning and supervision. WA helped in data analysis, interpretation of data, and revised the first draft manuscript. All authors discussed the results and commented on the manuscript. All authors read and approved the final manuscript.

\section{Funding}

This study was self-funded.

\section{Availability of data and materials}

The datasets used and/or analysed during the current study are available from the corresponding author on reasonable request.'

\section{Declarations}

Ethics approval and consent to participate

The Research Ethics Committee at the College of Medicine, University of Anbar approved the study. All students were informed of the study purpose and the voluntary and anonymous nature of participation, before providing written informed consent. The Research Ethics Committee at the College of Medicine, University of Anbar confirmed that parental consent was not required for the participation of children under the age of 16 .

\section{Consent for publication}

'Not Applicable'.

\section{Competing interests}

The authors declare that they have neither competing interests nor financial disclosure

\section{Author details}

${ }^{1}$ Family \& Community Medicine Department / Anbar Medical College, University of Anbar, Ramadi, Iraq. ${ }^{2}$ Family \& Community Medicine Department Al-Mustansiriya Medical College, University of Al-Mustansiriya, Baghdad, Iraq.

Received: 28 April 2020 Accepted: 25 June 2021

Published online: 05 July 2021

\section{References}

1. Al-Numair K, Barber-Heidal K, Al-Assaf A, El-Desoky G. Water-pipe (shisha) smoking influences total antioxidant capacity and oxidative stress of healthy Saudi males. J Food Agri Environ. 2007;5(3/4):17.

2. Hecht SS. Tobacco carcinogens, their biomarkers, and tobacco-induced cancer. Nat Rev Cancer. 2003;3(10):733-44. https://doi.org/10.1038/nrc1190.

3. Parkin DM, Bray F, Ferlay J, Pisani P. Global cancer statistics, 2002. CA Cancer J Clin. 2005;55(2):74-108. https://doi.org/10.3322/canjclin.55.2.74.

4. Sopori M. Effects of cigarette smoke on the immune system. Nat Rev Immunol. 2002;2(5):372-7. https://doi.org/10.1038/nri803.

5. Beaney T, Burrell LM, Castillo RR, Charchar FJ, Cro S, Damasceno A, et al. May measurement month 2018: a pragmatic global screening campaign to raise awareness of blood pressure by the International Society of Hypertension. Eur Heart J. 2019;40(25):2006-17. https://doi.org/10.1093/ eurheartj/ehz300.

6. Rashid AA, Devaraj NK. Oh no! Now I have diabetes. RMJ. 2018;43(4):776-8.

7. Chia YC, Ching SM, Chew BN, Devaraj NK, Siti Suhaila MY, Tay CL, et al. May Measurement Month 2017 blood pressure screening: findings from Malaysia_South-East Asia and Australasia. Eur Heart J Supp. 2019; 21(Supplement_D):D77-9.

8. Neergaard J, Singh P, Job J, Montgomery S. Waterpipe smoking and nicotine exposure: a review of the current evidence. Nicotine Tob Res. 2007; 9(10):987-94. https://doi.org/10.1080/14622200701591591.

9. Maziak W. The global epidemic of waterpipe smoking. Addict Behav. 2011 36(1-2):1-5. https://doi.org/10.1016/j.addbeh.2010.08.030.

10. Eissenberg T. Tobacco smoking using a waterpipe (hookah): what you need to know. AANA J. 2013;81(4):308-13.

11. Al Rashidi M, Shihadeh A, Saliba NA. Volatile aldehydes in the mainstream smoke of the narghile waterpipe. Food Chem Toxicol. 2008:46(11):3546-9. https://doi.org/10.1016/j.fct.2008.09.007. 
12. Cobb C, Ward KD, Maziak W, Shihadeh AL, Eissenberg T. Waterpipe tobacco smoking: an emerging health crisis in the United States. Am J Health Behav. 2010;34(3):275-85. https://doi.org/10.5993/AJHB.34.3.3.

13. Cobb CO, Shihadeh A, Weaver MF, Eissenberg T. Waterpipe tobacco smoking and cigarette smoking: a direct comparison of toxicant exposure and subjective effects. Nicotine Tob Res. 2010;13(2):78-87. https://doi.org/1 $0.1093 / \mathrm{ntr} / \mathrm{ntq} 212$

14. Shihadeh A, Saleh R. Polycyclic aromatic hydrocarbons, carbon monoxide,"tar", and nicotine in the mainstream smoke aerosol of the narghile water pipe. Food Chem Toxicol. 2005;43(5):655-61. https://doi. org/10.1016/j.fct.2004.12.013.

15. Eissenberg T, Shihadeh A. Waterpipe tobacco and cigarette smoking: direct comparison of toxicant exposure. Am J Prev Med. 2009;37(6):518-23. https://doi.org/10.1016/j.amepre.2009.07.014.

16. Singh T, Arrazola RA, Corey CG, Husten CG, Neff LJ, Homa DM, et al. Tobacco use among middle and high school students-United States, 2011-2015. Morb Mortal Wkly Rep. 2016;65(14):361-7. https://doi.org/10.1 5585/mmwr.mm6514a1.

17. Arrazola RA, Dube SR, King BA. Tobacco product use among middle and high school students—United States, 2011 and 2012. MMWR. 2013;62(45):893.

18. Majeed BA, Sterling KL, Weaver SR, Pechacek TF, Eriksen MP. Prevalence and harm perceptions of hookah smoking among US adults, 2014-2015. Addict Behav. 2017;69:78-86. https://doi.org/10.1016/j.addbeh.2017.01.032.

19. Akl EA, Jawad M, Lam WY, Obeid R, Irani J. Motives, beliefs and attitudes towards waterpipe tobacco smoking: a systematic review. Harm Reduct J. 2013;10(1):12. https://doi.org/10.1186/1477-7517-10-12.

20. Qasim H, Alarabi AB, Alzoubi KH, Karim ZA, Alshbool FZ, Khasawneh FT. The effects of hookah/waterpipe smoking on general health and the cardiovascular system. Environ Health Prev Med. 2019;24(1):1-7.

21. Khater AE, El-Aziz NS, Al-Sewaidan HA, Chaouachi K. Radiological hazards of Narghile (hookah, shisha, goza) smoking: activity concentrations and dose assessment. J Environ Radioact. 2008;99(12):1808-14. https://doi.org/10.101 6/j.jenvrad.2008.07.005

22. Hadidi KA, Mohammed FI. Nicotine content in tobacco used in hubblebubble smoking. Saudi Med J. 2004;25(7):912-7.

23. Smith-Simone S, Maziak W, Ward KD, Eissenberg T. Waterpipe tobacco smoking: knowledge, attitudes, beliefs, and behavior in two US samples. Nicotine Tob Res. 2008;10(2):393-8. https://doi.org/10.1080/1462220070182 5023 .

24. Salloum RG, Maziak W, Hammond D, Nakkash R, Islam F, Cheng X, et al. Eliciting preferences for waterpipe tobacco smoking using a discrete choice experiment: implications for product regulation. BMJ Open. 2015;5(9): e009497. https://doi.org/10.1136/bmjopen-2015-009497.

25. Scott-Sheldon LA, Stroud LR. Preferences and perceptions of flavored hookah tobacco among US women. Am J Health Behav. 2018;42(3):37-46. https://doi.org/10.5993/AJHB.42.3.4.

26. Afifi RA, Yeretzian JS, Rouhana A, Nehlawi MT, Mack A. Neighbourhood influences on narghile smoking among youth in Beirut. Eur J Pub Health. 2010;20(4):456-62. https://doi.org/10.1093/eurpub/ckp173.

27. Momenabadi V, Hashemi SY, Borhaninejad VR. Factors affecting hookah smoking trend in the society: a review article. Addict Health. 2016;8(2):123-35.

28. Griffiths MA, Harmon TR, Gilly MC. Hubble bubble trouble: the need for education about and regulation of hookah smoking. J Public Policy Mark. 2011;30(1):119-32. https://doi.org/10.1509/jppm.30.1.119.

29. Lipkus IM, Eissenberg T, Schwartz-Bloom RD, Prokhorov AV, Levy J. Affecting perceptions of harm and addiction among college waterpipe tobacco smokers. Nicotine Tob Res. 2011;13(7):599-610. https://doi.org/10.1093/ntr/ ntr049.

30. Thabit MF, Mohsin MA, Niazy SM. Water pipe (shisha) smoking among a sample of Iraqi male college students: knowledge and attitudes. Age (years). 2015:20:20-4.

31. Aday LA, Cornelius LJ. Designing and conducting health surveys: a comprehensive guide: Wiley; 2006. Available from: https://slideplayer.com/ slide/3420524/

32. Amin TT, Amr MA, Zaza BO, Suleman W. Harm perception, attitudes and predictors of waterpipe (shisha) smoking among secondary school adolescents in Al-Hassa, Saudi Arabia. Asian Pac J Cancer Prev. 2010;11(2): 293-301.

33. Al-Delaimy WK, Edland S, Zablocki RW. California Smokers Cohort (CSC) 2011. In: California smokers cohort (CSC): UC San Diego Library Digital Collections; 2016. https://doi.org/10.6075/J00V89RP.
34. Fakhari A, Mohammadpoorasl A, Nedjat S, Sharif Hosseini M, Fotouhi A. Hookah smoking in high school students and its determinants in Iran: a longitudinal study. Am J Mens Health. 2015;9(3):186-92. https://doi.org/1 $0.1177 / 1557988314535236$.

35. Alzyoud S, Weglicki L, Kheirallah K, Haddad L, Alhawamdeh K. Waterpipe smoking among middle and high school Jordanian students: patterns and predictors. Int J Environ Res Public Health. 2013;10(12):7068-82. https://doi. org/10.3390/ijerph10127068.

36. Azodi F, Sharif F, Azodi P, Shirazi ZH, Khalili A, Jahanpour F. The reasons of tendency toward hookah smoking among teens and youth in Iran-a qualitative study. J Pharm Sci Res. 2017;9(9):1642-6.

37. Bejjani N, El Bcheraoui C, Adib SM. The social context of tobacco products use among adolescents in Lebanon (MedSPAD-Lebanon). J Epidemiol Global Health. 2012;2(1):15-22. https://doi.org/10.1016/j.jegh.2012.02.001.

38. Aslam HM, Saleem S, German S, Qureshi WA. Harmful effects of shisha: literature review. Int Arch Med. 2014;7(1):16. https://doi.org/10.1186/17557682-7-16.

39. Fitzpatrick M, Johnson AC, Tercyak KP, Hawkins KB, Villanti AC, Mays D. Peer reviewed: adolescent beliefs about hookah and hookah tobacco use and implications for preventing use. Prev Chronic Dis. 2019;16. https://doi.org/1 0.5888/pcd16.180093.

40. Tamim H, Al-Sahab B, Akkary G, Ghanem M, Tamim N, Roueiheb ZE, et al. Cigarette and nargileh smoking practices among school students in Beirut, Lebanon. Am J Health Behav. 2007;31(1):56-63. https://doi.org/10.5993/A JHB.31.1.6.

41. Wilkinson J, Velten J. The role of faith in addiction counseling: a qualitative study of program viability. Int J Humanit Soc Sci. 2016;6(7):45-53.

42. Khader YS, Alsadi AA. Smoking habits among university students in Jordan: prevalence and associated factors. East Mediterranean Health J. 2008;14(4): 897-904.

43. Sajid KM, Akhter M, Malik GQ. Carbon monoxide fractions in cigarette and hookah (hubblebubble) smoke. JPMA. 1993;993:43.

44. Tomé G, de Matos MG, Simões C, Camacho I, Alves DJ. How can peer group influence the behavior of adolescents: explanatory model. Global J Health Sci. 2012:4(2):26-35. https://doi.org/10.5539/gihs.v4n2p26.

45. Gordis LE. Epidemiology. 4th ed: Saunders Elsevier; 2009.

\section{Publisher's Note}

Springer Nature remains neutral with regard to jurisdictional claims in published maps and institutional affiliations.
Ready to submit your research? Choose BMC and benefit from:

- fast, convenient online submission

- thorough peer review by experienced researchers in your field

- rapid publication on acceptance

- support for research data, including large and complex data types

- gold Open Access which fosters wider collaboration and increased citations

- maximum visibility for your research: over $100 \mathrm{M}$ website views per year

At $\mathrm{BMC}$, research is always in progress.

Learn more biomedcentral.com/submissions 